\title{
The effectiveness of influence of biocomposite of fungi Basidiomycota upon the emission of carbon dioxide from cattle manure
}

\author{
Vorobel M. ${ }^{1}$, Moroz V. ${ }^{2}$, Kaplinskyi V. ${ }^{3}$ \\ Institute of Agriculture of Carpathian Region of NAAS \\ 5 Hrushevskoho Str., Obroshyne village, Pustomytiv region, Lviv oblast, 81115, Ukraine \\ e-mail: ${ }^{1}$ vorobelmariia@gmail.com, ${ }^{2}$ veramoroz0@ gmail.com, ${ }^{3}$ vasyl.kaplinskiy@gmail.com
}

\begin{abstract}
Goal. To determine the effectiveness of the influence of biocomposite of fungi Basidiomycota in different dilutions on the emission of carbon dioxide from cattle manure at mesophilic conditions of anaerobic digestion (in vitro). Methods. The study was carried out with the use of chemical, analytical and mathematical-statistical methods. Results. By results of the conducted researches it is established that after entering biocomposite of fungi Basidiomycota in manure substrate of cattle, regardless of the ratio of dilution (1:10 and 1:5), they observed a decrease in anaerobic fermentation during the study period, as evidenced by a decrease in $\mathrm{pH}$ on $1.9-2.1$ units. It is established that at addition to metane-generating raw materials (cattle manure) of biocomposite of fungi Basidiomycota in dilution of 1:10 the output of carbon dioxide was below the control on $1.48 \mathrm{dm} 3$, and at a dilution of $1: 5-$ on $1.58 \mathrm{dm} 3$. Consequently, the use of biocomposite of fungi Basidiomycota in mesophilic conditions of anaerobic digestion of cattle manure (in vitro), in a dilution of $1: 10$ and $1: 5$ reduces the output of carbon dioxide, respectively, on $93 \%$ and $100 \%$. Conclusions. It is experimentally proved and scientifically substantiated the effective impact of biocomposite of fungi Basidiomycota in the emission of carbon dioxide from cattle manure. Based on the results obtained during the research it is found out that the most effective influence on the level of carbon dioxide detects biocomposite of fungi Basidiomycota in a dilution of 1:5, and therefore, it can be used as an effective means to reduce the level of carbon dioxide to maintain clean environment during the fermentation of by-products of animal origin.
\end{abstract}

Key words: organic matter, greenhouse gases, atmosphere, anaerobic fermentation, biocomposite. DOI: https://doi.org/10.31073/agrovisnyk202004-10

Successful development of the agrarian sector of economy is impossible without stable development of animal husbandry [1], which accounts for production of more than $33 \%$ of gross output in the structure of agro-industrial complex of Ukraine [2, 3]. The intensification of production of livestock products is accompanied by the formation of a large amount of waste the annual growth in the number of which causes a serious threat to the natural environment, its ecosystems, due to contamination air, water, soil, etc. and requires respect for balance between increasing production of products and new approaches in recycling and utilization of waste [2-10]. It is known, that in the process of rotting of organic substances of animal and plant origin gaseous substances are formed, including greenhouse gases, which falling into the atmosphere, absorb heat and detain thermal radiation from the surface of the planet, thereby raising the average air temperature lead to formation of atmospheric aerosol and acid rains, etc. [3, 5, 11]. The most common among greenhouse gases are carbonic gas $\left(\mathrm{CO}_{2}\right)$, methane $\left(\mathrm{CH}_{4}\right)$, and nitrous oxide $\left(\mathrm{N}_{2} \mathrm{O}\right)$, hydrofluorocarbons, perfluorocarbons, and sulfur hexafluoride - a direct-acting greenhouse gases as they directly cause the greenhouse effect $[2,11,12]$. In the process of an intensification of agrarian production growth release of greenhouse gases in the atmosphere is observed [3-5]. Thus, since 1800 concentration of carbonic gas in the atmosphere increased more than by $25 \%$, concentration of methane has more than doubled, concentration of nitrous oxide grew by $8 \%[3,13]$, and for the last decades the share of their influence on strengthening of greenhouse effect is, respectively $-\mathrm{CO}_{2}$ up to $50 \%, \mathrm{CH}_{4}-15 \%, \mathrm{~N}_{2} \mathrm{O}-$ about $5-6 \%$ of the general contribution to global warming $[11,12]$.

Agriculture on the scale at emissions of greenhouse gases, although concedes to energy and industry, but still is a powerful source of them, both in Ukraine and in global scale $[3,6,14]$. In particular, according to the assessments of the World organization for food and agriculture, the animal husbandry is responsible for $18 \%$ of all emissions of greenhouse gases - it is more than emissions from transport $(14 \%)[4,7,15-17]$. According to the last estimates by the Food and Agriculture Organization of the United Nations (FAO) [18], emissions of greenhouse gases in the agriculture, forestry and fish sectors increased practically twice the last 50 years and have a tendency to the further growth on $30 \%$ by $2050 \mathrm{y}$. if are not carried out a number of measures for improvement of an ecological situation.

Consequently, agriculture in general, and the branch of animal husbandry in particular has a considerable influence on the environment and is an important source of pollution, that causes climate changes, resulting in the problem of minimization at emissions of greenhouse gases becomes one of the most important for mankind $[9,10]$. In this context, the development and realization of appropriate measures aimed at limiting at emissions of greenhouse gases in the future is essential importance. 
One of the ways reduces the level of greenhouse gases, and in particular carbonic gas, is increase their absorbers, namely afforestation of the territory of the state by restoration of the woods and afforestation (the average forest cover of Ukraine is $15,9 \%$ and the average forest cover of European countries is $37 \%$ ) [16]. As it is known that forests of the world annually absorb up to 25 billion tonnes of carbonic gas, however, is not able to fully reduce the concentration emissions of greenhouse gases into the environment [19]. Another way of reducing at emissions greenhouse gas from waste of livestock while simultaneous utilization is their use as alternative energy source by an anaerobic fermentation of biomass, that allows to receive high quality organic fertilizer and biogas that is suitable for producing electric or thermal energy [3, 9, 17].

Taking into account the above, the problem waste management of the branch of animal husbandry, which are one of the largest pollutants of harmful gases of the natural environment, remains relevant, and therefore the search for effective means for decrease level of their emissions from dung of cattle has important scientific and practical importance for solution environmental problems of activity of agro-industrial complex as a whole.

The purpose of the researches is to determine the effectiveness of the action biocomposition of fungi Basidiomycota in different dilutions on the level emission of $\mathrm{CO}_{2}$ with dung of cattle under mesophilic conditions of anaerobic fermentation (in vitro).

Materials and methods. The researches was conducted in the laboratory of ecology of the Institute of agriculture of the Carpathian region NAAS. Dung samples for determining efficiency of the influence biocomposition of fungi Basidiomycota in different dilutions on the level emission of $\mathrm{CO}_{2}$ taken in $\mathrm{SE}$ «EF Obroshyne», where the herd of Ukrainian black-and-white dairy cattle (western intra-breed type) is kept. The methane forming raw materials (dung) investigated in triple repeated in the such variants: I variant - control (dung without the introduction of preparation), II variant - biocomposition of fungi Basidiomycota in dilution 1:10; III variant - biocomposition of fungi Basidiomycota in dilution 1:5.

The process of methane fermentation was conducted in vitro. Biomass (dung of cattle) was introduced into an experimental a capacity diluted with water in corellation of 1:1. During an experiment conducted mixing of the investigated substrate by intensive shaking of the capacities. Analogical conditions the process of methanogenesis were as in the control variant, where the anaerobic fermentation of the substrate was due to the natural microflora of dung, as and in the experimental of analogues with the use different variants dilutions biocomposition of fungi Basidiomycota.

The amount of $\mathrm{CO}_{2}$ in the dung mass was determined by the method of N.V. Chibisova [20].

The method of V. Shatskyy, O. Sklyar and R. Sklyar was used as the basis for the research [21]. An important factor the process of methanogenesis is maintaining at the optimal indexes of fermentation. Therefore, in the process of realization of experiment at every stage of methanogenesis of the dung (hydrolysis, oxidation, acetogenesis, methanogenesis) in all variants an optimal temperature regime was supported and control of the level $\mathrm{pH}$ of the environment.

The acidity was determined using a device pH-Meter Type N5170 (production of Poland).

The statistical analysis of the obtained results of researches was conducted with the use the methods of variation statistics with the help a standard package Microsoft Excel and AtteStat application programs. The arithmetic averages value $(\mathrm{M})$ and an error of arithmetic averages $(\mathrm{m})$ were calculated. The difference between the arithmetic averages values was considered statistically probable at: ${ }^{*} p<0.05 ;{ }^{* *} p<0.01$; ${ }^{* * *} \mathrm{p}<0.001$.

Research results. The research was conducted under a mesophilic regime of fermentation while maintaining the temperature within $33^{\circ} \mathrm{C}$. In the procces of the experiment, reaction of the nutrient environmental $(\mathrm{pH})$, which determines the orientation of anaerobic fermentation, was investigated. During the fermentation of dung under mesophilic conditions, namely of passing of the stages: hydrolysis, oxidation (acidogenesis), the formation of acetate (acetogenesis), which amounted to 33 days, in the control and in the experimental variants it is established growth the level $\mathrm{pH}$ from 6.5 to 7.6 units (Fig. 1).

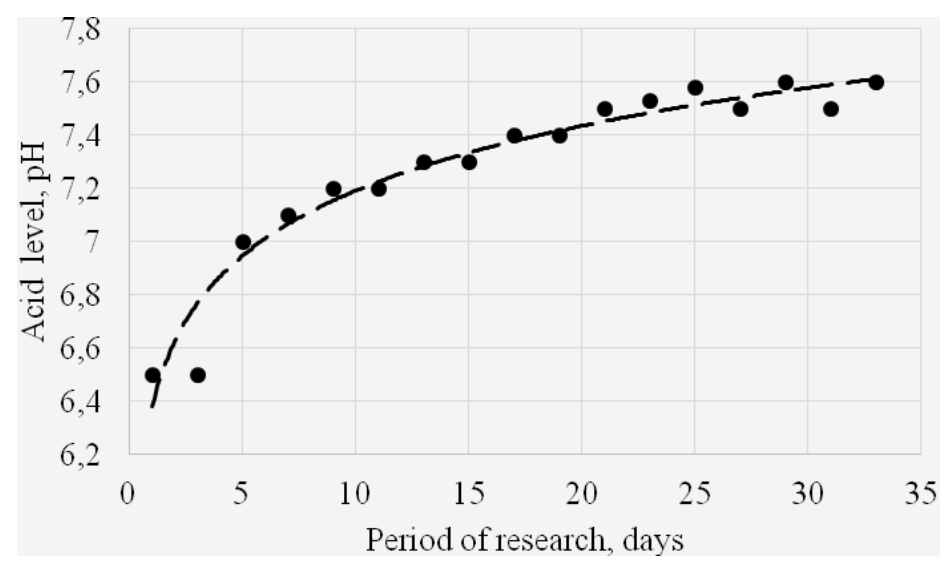

Fig. 1. Change the level of acidity before the introduction biocomposition of fungi Basidiomycota during the period flowing of the process of methanogenesis 
On the 34 day at the level $\mathrm{pH}$ in the investigated substrate (dung of cattle ) of 7.6 units the beginning of the process of methanogenesis was introduced biocomposition of fungi Basidiomycota in different dilutions $1: 10$ and 1:5. In further researches, after the introduction biocomposition of fungi Basidiomycota into the methane forming raw material, the $\mathrm{pH}$ reduce from 7.6 to $5.5-5.7$ units respectively, at a dilution of $1: 5$ and 1:10 was observed (Fig. 2).

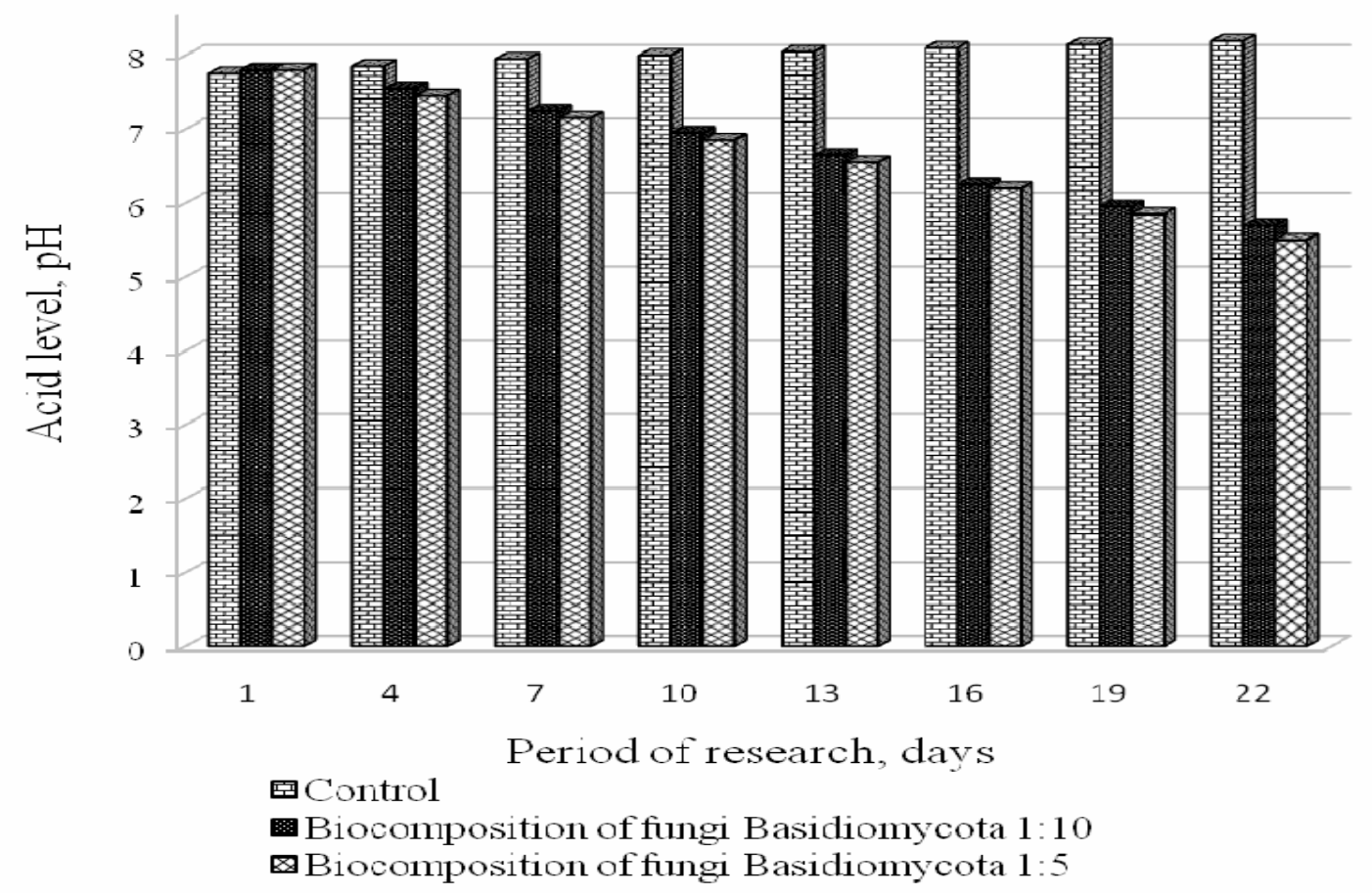

Fig. 2. Change the level of acidity during the period a realization of researches with use biocomposition of fungi Basidiomycota

One of the important indicators of anaerobic fermentation is also the time of the process of fermentation of biomass (exposition of fermentation). In most cases, at the processing of organic wastes the stage of methanogenesis occurs during a 22-28 days and depends on a temperature regime [22]. In this experiment, the exposition of anaerobic fermentation was in the recommended limits and was 23 days.

Therefore, according to the results of the researches, it is established that after the introduction into the dung of cattle, biocomposition of fungi Basidiomycota in different dilutions (1:10 and 1:5) during the investigated period - 22 days were observed decrease processes of anaerobic fermentation, that is confirmed by a reduction in $\mathrm{pH}$.

In the process of carrying out an experiment in the conditions of in vitro, on the 34 day and through each three days, carried out determination of the level of emissions $\mathrm{CO}_{2}$ with dung of cattle in control and using biocomposition of fungi Basidiomycota in different dilutions of 1:10 and 1:5. Analyzing of the obtained results of researches it is established that the level emission of $\mathrm{CO}_{2}$ with dung of substrate at the introduction biocomposition of fungi Basidiomycota in dilution of $1: 10$ was lower than the control by $1,48 \mathrm{dm}^{3}$, and at a dilution of $1: 5-$ by $1,58 \mathrm{dm}^{3}$ (Table).

Action biocomposition of fungi Basidiomycota on the emissions of $\mathrm{CO}_{2}$ was more effective in dilution of 1:5 for the entire period of researches. In addition, the substrate had no specific odor the dung of cattle.

Volume of selegted carbonic gas in the process of methanogenesis at introduction biocomposition of fungi Basidiomycota in dilution of 1:10 and 1:5, $\mathrm{dm}^{3}$

\begin{tabular}{|c|c|c|c|}
\hline Days & Control & $\begin{array}{c}\text { Biocomposition of fungi } \\
\text { Basidiomycota 1:10 }\end{array}$ & $\begin{array}{c}\text { Biocomposition of fungi } \\
\text { Basidiomycota } 1: 5\end{array}$ \\
\hline 1 & $1,123 \pm 0,031$ & $0,056 \pm 0,009^{* * *}$ & $0,001 \pm 0,000085^{* * *}$ \\
\hline 4 & $1,263 \pm 0,12$ & $0,072 \pm 0,02^{* * *}$ & $0,001 \pm 0,0001^{* * *}$ \\
\hline 7 & $1,414 \pm 0,08$ & $0,091 \pm 0,01^{* * *}$ & $0,001 \pm 0,000084^{* * *}$ \\
\hline 10 & $1,414 \pm 0,041$ & $0,095 \pm 0,002^{* * *}$ & $0,001 \pm 0,00007^{* * *}$ \\
\hline 13 & $1,414 \pm 0,06$ & $0,097 \pm 0,004^{* * *}$ & $0,002 \pm 0,0001^{* * *}$ \\
\hline 16 & $1,414 \pm 0,06$ & $0,099 \pm 0,003^{* * *}$ & $0,002 \pm 0,0001^{* * *}$ \\
\hline 19 & $1,414 \pm 0,04$ & $0,097 \pm 0,004^{* * *}$ & $0,002 \pm 0,0001^{* * *}$ \\
\hline 22 & $1,577 \pm 0,035$ & $0,096 \pm 0,005^{* * *}$ & $0,001 \pm 0,0002^{* * *}$ \\
\hline
\end{tabular}


Therefore, at introduction into the dung of cattle biocomposition of fungi Basidiomycota under mesophilic regime fermentation in anaerobic conditions, regardless at a dilution (1:10 and 1:5), reduces the emission of $\mathrm{CO}_{2}$ in the investigated of substrate with dung of cattle. In addition, biocomposition of fungi Basidiomycota reduces the unpleasant odor of dung, that can be of practical importance when used in the branch of animal husbandry.

\section{Conclusions}

Experimentally it is confirmed and scientifically proved that the use biocomposition of fungi Basidiomycota under mesophilic condition of anaerobic fermentation the dung of cattle (in vitro) in dilution 1:10 and 1:5, reduces the output of carbonic gas by 93 and 100\%, respectively. The level pH at the processes of biofermentation before the introduction biocomposition of fungi Basidiomycota increases by 1,3 units, and after its use in various dilutions - 1:10 and 1:5 decreases by 1,9-2,1 units. Therefore, it is advisable to use the biocomposition of fungi Basidiomycota in dilutions 1:10 and 1:5 both for decontamination of fermentative processes and for reducing the emisions of $\mathrm{CO}_{2}$ with dung of cattle, that will help to prevent natural environmental of pollution.

In future it is planned to conduct the experimental research of the process of anaerobic fermentation the dung of cattle (in vivo) at the use biocomposition of fungi Basidiomycota and to search for other effective means for reducing of carbonic gas emissions and also methane and nitrous oxide, etc. with of by-products of animal origin into the natural environment for solving ecological problems activities of the agro-industrial complex.

\section{References}

1. Demchuk, M. V., Reshetnyk, A. O., \& Laiter-Moskaliuk, S. V. (2010). Problemy utylizatsii gnoiu v suchasnomu tvarynnytstvi [Problems of dung utilization in modern animal husbandry]. Scientific Bulletin of Lviv National University of Veterinary Medicine and Biotechnology named after S. Z. Gzhitsky, 12 (3(4)), 188-195. [In Ukrainian].

2. Khodorchuk, V. Ya., Aliieva, I. V., \& Martkoplishvili, M. M. (2014). Minimizatsiia emisii parnykovykh gaziv u silskomu gospodarstvi [Minimization of greenhouse gas emissions in agriculture]. Agrarian bulletin of the South, 1, 168-173. [In Ukrainian].

3. Binkovska, H. V., \& Shanina, T. P. (2016). Otsinka obsiagiv vykydiv parnykovykh gaziv u systemakh povodzhennia z silskogospodarskymy vidkhodamy Odeskoi oblasti [Evaluation of greenhouse gas emissions in the systems of handling agricultural wastes in Odessa region]. Bulletin of Kharkiv National University named after V. N. Karazin, 14, 91-97. [In Ukrainian].

4. Binkovska, H. V., \& Shanina, T. P. (2013). Vidkhody tvarynnytstva ta ptakhivnytstva yak syrovyna dlia vyrobnytstva biogazu $v$ Odeskii oblasti [Animal husbandry and poultry wastes as raw material for biogas production in Odessa region]. Bulletin of the Odessa state ecological university, 15, 28-34. [In Ukrainian].

5. Zhukorskyi, O. M., \& Boltyk, N. P. (2017). Zabrudniuvachi dovkillia ta yikh vykorystannia dlia vyrobnytstva biogazu na molochnykh fermakh [Pollutants of the environmental and their use for dairy farm biogas production]. Scientific bulletin "Askania-Nova”, 10, 250-259. [In Ukrainian].

6. Pinchuk, V. O. (2015). Emisiia parnykovykh gaziv v haluzi tvarynnytstva Ukrainy [Emissions of greenhouse gases in the field of animal husbandry of Ukraine]. Biological resources and nature management, 7(1/2), 115-118. [In Ukrainian].

7. Bailey, R., Froggatt, A., Wellesley, L. (2014) Livestock - climate change's forgotten sector global public opinion on meat and dairy consumption. Energy, Environment and Resources.

8. Zakharenko, M. O., Yaremchuk, O. S., Shevchenko, L. V. Poliakovskyi, V. M., Mykhalska, V. M., Maliuha, L. V., \& Kovalenko, V. O. (2015). Biotekhnologiia vidkhodiv tvarynnytskykh pidpryiemstv [Biotechnology of waste of the animal enterprises]. A monograph. Kyiv: National University of Life and Environmental Sciences of Ukraine. [In Ukrainian].

9. Smith, D. W. (2014). Mitigation of greenhouse gas emissions in animal agriculture. Animal agriculture in a changing climate, $1,1-7$.

10. Petersen, S. O., Blanchard, M., Chadwick, D., Del Prado, A., Edouard, N., Mosquera, J., \& Sommer, S. G. (2013). Manure management for greenhouse gas mitigation. Animal, 7, $266-282$. doi: 10.1017/S1751731113000736.

11. Mykhailova, Ye. O. (2016). Vykydy parnykovykh gaziv v Ukraini ta sviti [Greenhouse gas emissions in Ukraine and in the world]. Problemy tekhnogenno-ekologichnoi bezpeky: osvita, nauka, praktyka: zbir. mater. Vseukr. nauk.-prakt. konf. [Problems of technogenic and ecological safety: education, science, practice: collection of materials All-Ukrainian sciences-practice conf.]. (pp. 183-184). Ukraine, Kharkov. ISBN 978617-7256-55-6. [In Ukrainian].

12. Kholod, M. (2009). Emisiia parnykovykh gaziv ta formuvannia rynku kvot na yikh vykydy [The emission of greenhouse gases and the formation of the market of quotas on emissions]. Bulletin of Sumy SU, 2, 35-42. [In Ukrainian].

13. IPCC (Intergovernmental Panel on Climate Change) (1992). Climate Change 1992: The Supplementary Report to the IPCC Scientific Assessment. Cambridge: Cambridge University Press.

14. Steinfeld, H., Gerber, P., Wassenaar, T., Castel, V., Rosales, M., Cees de Haan (2006). Livestock's long shadow: environmental issues and options. Rome. https: //www.virtualcentre.org.

15. Ekologichni standarty YeS dlia galuzi tvarynnytstva Ukrainy. (2018). [Environmental standards of the 
EU for branch of livestock production of Ukraine]. Kyiv. https: //ecoaction.org.ua > EkoStandartEU_short-s. [In Ukrainian].

16. Moran, D., Wall, E. (2011). Livestock production and greenhouse gas emissions: Defining the problem and specifying solutions. Animal Frontiers, 1(6), 19-25. https://doi.org/10.2527/af.2011-0012.

17. Hristov A. N., Oh, J., Lee, C., Meinen R., Montes F., Ott, T., ... Oosting, S. (2013). Mitigation of

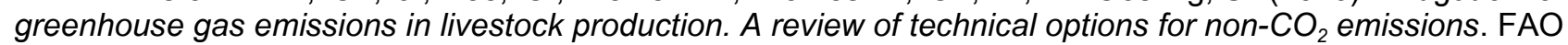
Rome.

18. Tubiello, F. N., Salvatore, M., Cóndor Golec, R.D., Ferrara, A., Rossi, S., Biancalani, R., ... Flammini, A. (2014). Agriculture, forestry and other land use emissions by sources and removals by sinks. 1990-2011 Analysis. FAO Statistics Division, Working Paper Series ESS/14-02.

19. Furdychko, O. I., Boiko, A. L. (eds.) (2013). Ekolohichna bezpeka agropromyslovogo vyrobnytstva [Ecological safety agro-industrial production]. Kyiv: DIA Publ. [In Ukrainian].

20. Chibisova, N. V. (1999) Praktikum po ekologicheskoi khimii: Uchebnoe posobie [Practical work on ecological chemistry: Study guide]. Kaliningrad: Kaliningrad: Kaliningrad University. [In Russian].

21. Shatskyi, V. V., Skliar, O. H., Skliar, R. V., \& Solodka, O. O. (2013). Vplyv struktury substratu na vykhid biogazu pry metanovomu zbrodzhuvanni [Influence of substrate structure on biogas output at methane fermentation]. Proceedings of the Tavriya State Agrotechnological University, 13(3), 3-12. [In Ukrainian].

22. Polishchuk, V. M., Lobodko, M. M., Sydorchuk, O. V., \& Polishchuk, O. V. (2013). Vplyv rezhymiv metanovogo brodinnia na efektyvnist vyrobnytstva biogazu [Influence the regimes of methane fermentation on efficiency biogas production]. Scientific bulletin of National University of Life and Environmental Sciences of Ukraine, 185(3), 180-191. [In Ukrainian]. 